\title{
Lung Cancer pT1c TNM Finding v8
}

National Cancer Institute

\section{Source}

National Cancer Institute. Lung Cancer pT1C TNM Finding v8. NCI Thesaurus. Code C136452.

Lung cancer with tumor measuring more than $2 \mathrm{~cm}$ but $3 \mathrm{~cm}$ or less in greatest dimension. (from AJCC 8th Ed.) 